Supplement of Clim. Past Discuss., 11, 2889-2931, 2015

http://www.clim-past-discuss.net/11/2889/2015/

doi:10.5194/cpd-11-2889-2015-supplement

(C) Author(s) 2015. CC Attribution 3.0 License.

(c) (i)

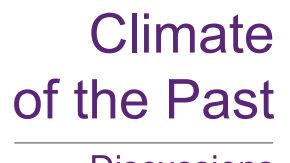

Discussions

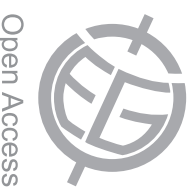

Supplement of

\title{
A massive input of coarse-grained siliciclastics in the Pyrenean Basin dur- ing the PETM: the missing ingredient of a coeval abrupt change in hydro- logical regime
}

\author{
V. Pujalte et al. \\ Correspondence to: V. Pujalte (victoriano.pujalte@ehu.eus)
}

The copyright of individual parts of the supplement might differ from the CC-BY 3.0 licence. 


\section{Pujalte, J. I. Baceta, and B. Schmitz A massive input of coarse-grained siliciclastics in the Pyrenean Basin during the PETM: the missing ingredient of a coeval abrupt enhancement of seasonal precipitation. SUPPLEMENTARY FIGURES}

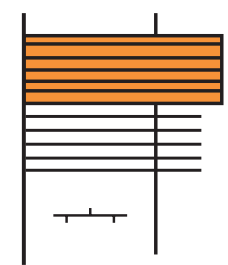

Sandstone beds predominantly thicker than $250 \mathrm{~cm}$

Sandstone beds $50-250 \mathrm{~cm}$ Interbedded calciturbidites and hemipelagic deposits

Fig. 1. Distribution of calcareous nannoplankton species from the Orio area according to van Vliet (1982).Slightly modified from his enclosure 3 (log) and from Appendix Ic (nannofossil distribution). Note that no nannofossils occur in the sandstone interval. The distribution of Tribrachiatus contortus in the succession overlying the sandstone interval is highlighted.

Fig. 2. Arenaza quarry (abandoned): (A) General view showing the reddish colour of Unit $D$ (quartz sands) in weathered exposures. (B and C) General view and close-up of the hematite concentration interval at the top of Unit D.
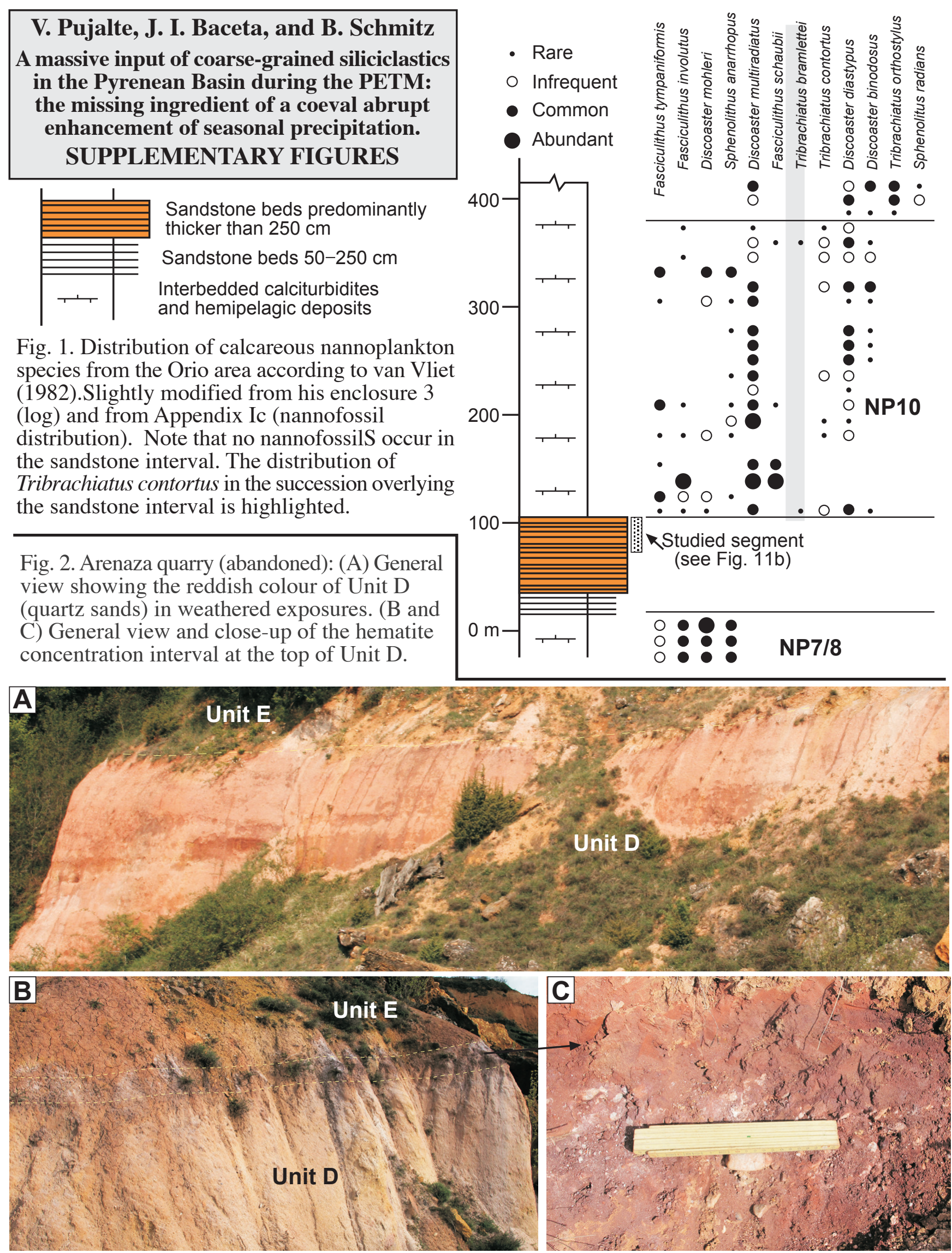